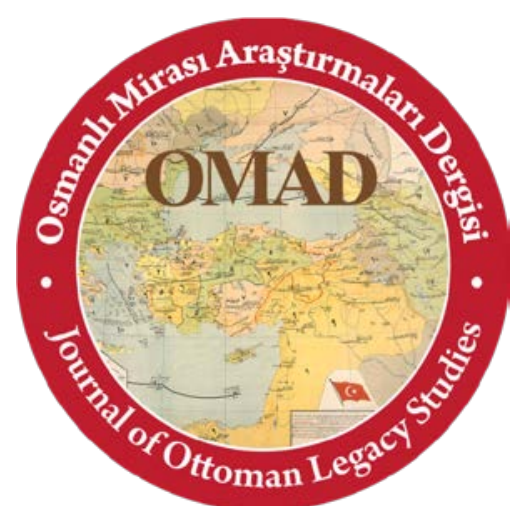

Osmanlı Mirası Araştırmaları Dergisi / Journal of Ottoman Legacy Studies

ISSN 2148-5704

www.osmanlimirasi.net

osmanlimirasi@gmail.com

Cilt 6, Sayı 14, Mart 2019 / Volume 6, Issue 14, March 2019

\title{
THE LAST SENATOR: ALI PASHA RIZVANBEGOVIĆ
}

Son Ayan: Ali Paşa Rizvanbegoviç

Makale Türü/Article Types : Araştırma Makalesi/Research Article

Geliş Tarihi/Received Date : 13.01.2019

Kabul Tarihi/Accepted Date : 20.02.2019

Sayfa/Pages : 243-255

DOI Numaras1/DOI Number : http://dx.doi.org/10.17822/omad.2019.122

\section{ZAFER GÖLEN}

(Prof. Dr.), Burdur Mehmet Akif Ersoy Üniversitesi, Fen-Edebiyat Fakültesi, Tarih Bölümü, Burdur / Türkiye, e-mail: zgolen@gmail.com, ORCID: https:/ / orcid.org/0000-0003-3162-6076

\section{Atıf/Citation}

Gölen, Zafer, "The Last Senator: Ali Pasha Rizvanbegović", Osmanlı Mirası Araştırmaları Dergisi, 6/14, 2019, s. 243-255.

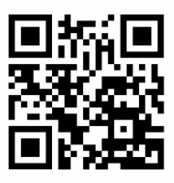

[] Scan me 

Osmanlı Mirası Araştırmaları Dergisi (OMAD), Cilt 6, Sayı 14, Mart 2019.

Journal of Ottoman Legacy Studies (JOLS), Volume 6, Issue 14, March 2019.

ISSN: $2148-5704$

\title{
THE LAST SENATOR: ALI PASHA RIZVANBEGOVIĆ Son Ayan: Ali Paşa Ruzvanbegoviç
}

\section{ZAFER GÖLEN}

\begin{abstract}
Muslims were subjected to privileged treatment since the conquest in Bosnia-Herzegovina. They became a part of the Ottoman system and acted as its most powerful supporters by transforming into governors, landowners, notables, sipahis or janissaries. In response, the state did not interfere with their autonomous structure. Bosnia-Herzegovina acted merely as an autonomous province in its internal affairs. The governors sent from the capital were treated only as respectable guests. One of them was Ali Pasha Rizvanbegović. Ali Pasha supported Istanbul during the independence war of Hussein Pasha Gradasević and played an important role in his defeat. Istanbul appointed him as the Mutasarif of Herzegovina for this service. From 1832 to 1851, Ali Pasha became the sole ruler of Herzegovina. He built roads and water channels for the development of Herzegovina and signed important trade agreements with Austrians. He prevented the development of Montenegro which was the biggest problem of the Ottomans in the region. He hindered the Serbian independence. However, when the Tanzimat was proclaimed in 1839, Ali Pasha opposed the implementation of the Tanzimat reforms in Bosnia, with the concern that it would lead to the end of Ottoman rule in Bosnia. The Ottoman government tolerated this situation until 1849. When the Tanzimat was implemented in Bosnia and Herzegovina in 1849, Ali Pasha and all the Bosnians opposed it with all their power. Unfortunately, this time Istanbul was ruthless and the famous general Omer Pasha Latas, known for his hatred for the Bosnians, was sent to Bosnia. Pasha showed no mercy in Bosnia. Eventually, Ali Pasha was defeated. He suffered uncalled-for insults and was finally killed. His family and surviving children were forced to live in Istanbul. In this paper, the works of Ali Pasha during the nineteen years, between 1832 and 1851, which he ruled in Herzegovina, will be examined in the light of the Ottoman Archive documents.
\end{abstract}

Keywords: Ottoman Empire, Bosna Province, Herzegovina, Montenegro, Ali Pasha Rizvanbegović

Öz: Müslümanlar fetihten itibaren Bosna Hersek’te ayrıcalıklı muameleye tabi tutuldular. Onlar bey, ağa, eşraf, sipahi veya yeniçeri olarak Osmanlı sisteminin bir parçasına ve en güçlü destekçisine dönüştüler. Buna karşı devlet de onların özerk yapısına dokunmadı. Bosna Hersek iç işlerinde âdeta özerk bir eyalet gibi kaldı. Merkezden gelen valiler Bosna'da saygın bir misafirin ötesine geçemedi. Bu beylerden birisi de Ali Paşa Rızvanbegoviç’tir. Ali Paşa, Hüseyin Paşa Gradaseviç'in bağımsızlık savaşında İstanbul'u destekledi ve Hüseyin Paşa'nın yenilmesinde önemli rol oynadı. İstanbul da bu hizmeti karşıllğında onu Hersek mutasarrıfı tayin etti. Ali Paşa 1832'den 1851'e kadar Hersek'in tek hâkimi oldu. Hersek'in gelişmesi için yollar, su kanalları yaptırdı. Avusturyalılarla önemli ticaret antlaşmalarına imza attı. O sağken Osmanlı Devleti'nin bölgedeki en büyük problemi Karadağ'ın gelişimini engelledi. Sırp bağımsızlığına engel oldu. Ancak 1839'da Tanzimat ilan edilince Ali Paşa Bosna'nın Osmanlı elinden çıkacağı endişesi ile Tanzimat reformlarının Bosna'da uygulanmasına muhalefet etti. Osmanlı Hükümeti 1849'a kadar bu durumu hoş gördü. 1849'da Bosna Hersek'te Tanzimat uygulanmaya başlayınca Ali Paşa ve tüm Boşnaklar olanca güçleri ile Tanzimat'a muhalefet etti. Bu kez İstanbul acımasız davrandı ve Boşnaklardan nefreti ile bilinen ünlü General Ömer Paşa Latas, Bosna'ya gönderildi. Paşa, Bosna'da kimseye acımadı. Sonunda Ali Paşa yenildi ve öldürüldü. Ailesi ve sağ kalan çocukları İstanbul'da oturmaya mecbur edildi. Çalışmada Ali Paşa'nın Hersek'te hüküm sürdügü 1832-1851 yılları arasındaki 19 yıllık icraatları Başbakanlık Osmanlı Arşiv vesikaları 1şı̆̆ında ortaya konulmaya çalışılacaktır.

Anahtar Kelimeler: Osmanlı Devleti, Bosna Eyaleti, Hersek, Karadağ, Ali Paşa Rızvanbegoviç 


\section{Introduction}

Ali Pasha ${ }^{1}$ was born in 1783 in Stolac. His father, Zulfikar Captain, was the captain of Stolac. ${ }^{2}$ Ali Pasha's mother, Melikhane, was the youngest daughter of Bosnian Muteselim ${ }^{3}$ Hadji Omer Babić. Zulfikar Captain first married Omer Babić's eldest daughter, but when she died, he married Babić's other daughter, Melikhane. He had two sons from his first wife, Mustafa ${ }^{4}$ and Mehmed (Hacun 1768-1832) ${ }^{5}$; and had four sons, Ali, Omer, Dervish, Halil and a daughter, Fatma, from his second wife, Melikhane. Hadji Mustafa Beg (1763-1813), whose mother was Zulfikar's first wife, became the captain of Stolac following his father's health in 1802. After the death of Zulfikar Captain in 1805, his children started to fight among themselves for the captaincy. ${ }^{6}$ The struggle for the captaincy of Stolac among the brothers ended with the death of Hadji Mustafa Captain in 1813. That year, Hadji Mehmed Captain withdrew to Hutova and left the captaincy of Stolac to his younger brother Ali Pasha. ${ }^{7}$

\section{Ali Pasha Until Herzegovina Mutasarrifate}

Ali Aga, being the holder of a small but strategic captaincy like Stolac, had always sided himself with the state in all of the conflicts of the early 19th century. ${ }^{8}$ His first direct support was during the abolition of Janissaries in Bosnia, and he managed to resolve this issue in Ljubinje, Nevesinje and Mostar, without any problems. In addition, he went to Zvornik with 100 gunmen in order to support Abdurrahman Pasha, who was appointed as the governor of Bosnia to suppress the rebellion. ${ }^{9}$ Therefore, Ali Aga, who gained a respectable position in the eyes of the governor, has mediated between the notables and the state during the punishments in Sarajevo after the rebellion. ${ }^{10}$ His mediating between the Bosnian notables and the governor is an indication of his privileged position.

Ali Aga stood up the state even after Hussein Pasha rebelled in 1832. The fact that he and Smail Aga Čengić supported the state also affected other captains in Herzegovina, and prevented the captains of Nevesinje, Nikshić and Trebigne from supporting the rebellion as well. He saved Bosnian Governor Ali Namik Pasha from the rebels and helped him leave Bosnia. ${ }^{11}$ His activities enraged Hussein Pasha who dismissed him from the Muteselimate of Herzegovina and replaced him with Osman Beg who was one of his own supporters. When Ali Pasha refused this appointment, he was besieged in Stolac by Osman Beg. These were very troubled days for Ali Aga, nonetheless he continued to support the state. It is understood that Stolac was a place of refuge for the opponents of Hussein Captain during the conflicts. ${ }^{12}$

\footnotetext{
${ }^{1}$ He signs himself Ali Ghaleb or “the Conqueror”. See, John Gardner Wilkinson, Dalmatia and Montenegro, vol. II, John Murray, London 1848, p. 74.

${ }^{2}$ H. Mirgül Eren Griffe, Osmanlının Hizmetkarı Galip Ali Paşa Rızvanbegovic-Stocevic, Babil Yayın Dağıtım, Ankara 2005, p. 138.

${ }^{3}$ Deputy lieutenant-governor, and local collector of taxes and tithes. See, Pars Tuğlacı, Okyanus Ansiklopedik Sözlük, vol. VI, Cem Yay., İstanbul 1980, p. 2077.

${ }^{4}$ When Mustafa's son Ebubekir died in 1835, his timar was left to his uncle. He was also a partner of the timar. Therefore, the timar was a joint one. Hence, it is referred that Zulfikâr Captain also had timar as well as captaincy and the family held the timar as ocaklık. See, DAB., HAT., nr:604/29542, 29 Zilhicce 1250/28.04.1835.

${ }^{5}$ Hadji Mehmed Bey was shot to death by Ali Paşa on February 27, 1832. See, Griffe, ibid., p. 119, 156-161, 166, 171.

${ }_{7}^{6}$ Griffe, ibid., p. 154-155.

${ }^{7}$ Griffe, ibid., p. 158; Mustafa L. Bilge, "Ridvanbegoviç, Ali Paşa", Türkiye Diyânet Vakfi İslâm Ansiklopedisi, vol. XXXV, Türkiye Diyânet Vakfi Yay., İstanbul 2008, p. 50.

${ }^{8}$ Safvet Beg Başagiç (Recepaşiç), Bosna Hersek Tarihi (1463-1850), Translated by Saffet Atalay, Kastaş Yay., İstanbul 2015, p. 205.

${ }^{9}$ Fatma Sel Turhan, Eski Düzen Adına. Osmanlı Bosna 'sında İsyan (1826-1836), Küre Yay., İstanbul 2013, p. 113, 118.

${ }^{10}$ Başagiç, ibid., p. 213.

${ }^{11}$ Başagiç, ibid., p. 218-221; Sel Turhan, ibid., p. 137; Griffe, ibid., p. 177.

${ }^{12}$ Başagiç, ibid., p. 224-225; Sel Turhan, ibid., p. 157.
} 
In the following months, Ali Aga's reputation in the eyes of the state has increased steadily. It was even considered that he would be appointed as the governor of Bosnia after Ibrahim Pasha. Grand Vizier Rashid Mehmed Pasha, in particular, was in favor of Ali Aga to be governor. However, with the concern that other captains might be jealous of Ali Aga in case he became the governor, the governorship of Ali Aga was not realized. ${ }^{13}$ That is why Mahmud Hamdi Pasha replaced Ibrahim Pasha as the governor of Bosnia.

Ali Aga and Smail Aga Čengić ${ }^{14}$ supported the state yet again in the Battle of the Palace on June 4, 1832, when the fate of Hussein Captain and of the entire Bosnia was sealed. During the battle that lasted 7 hours, just when the governor Mahmud Hamdi Pasha decided to withdraw, the forces of Ali and Smail Aga reached the battlefield and the battle was won. Ali Aga has been rewarded for his services with the "nişân-i iftihâr" medal given only to those who bring great benefit to the state. ${ }^{15}$

Consequently, as a result of his services, his rank was elevated to vizier in September 1832 and he was appointed as a fully authorized mutasarif ${ }^{16}$ in Bosnia at the end of the same year. ${ }^{17}$ However, with this appointment a new disturbance arose. Bosnia was divided in two groups, one supporting Hussein Captain and the other supporting Ali Pasha. The supporters of Hussein Captain created unrest to wear Ali Pasha down and refused to recognize the muteselim appointed by governor Mahmud Pasha. Particularly, they stressed the public by spreading rumors such as "Hussein Captain was appointed as the governor of Bosnia". ${ }^{18}$ In addition, Mahmud Hamdi Pasha, the Governor of Bosnia, was also against the appointment of Ali Pasha as mutasarlf.

He sent his report consisting of his objections to Istanbul without delay. According to him, since Ali Pasha was a local, other elders would be jealous of him. Moreover, the separation of Herzegovina from Bosnia could harm the integrity of these two complementary regions. Therefore, Herzegovina should be merged again with Bosnia and Ali Pasha should be assigned to another duty with a suitable rank. ${ }^{19}$ Needless to say, his warnings were not taken into consideration in the capital. On the contrary, this report served as evidence that he could not get along with the Bosnians and especially with Ali Pasha, and he was on the verge of being dismissed. Ali Pasha played an important role in provoking Istanbul against Mahmud Hamdi Pasha. ${ }^{20}$ The capital did not hesitate to dictate that the decisions being taken would be in line with the reports of Ali Pasha. ${ }^{21}$ Eventually, Mahmud Hamdi Pasha was dismissed on Ali Pasha's request and replaced with Davud Pasha. Even the official who would be in charge of overseeing the office of the governor during this change was asked to Ali Pasha. ${ }^{22}$

Ali Pasha not only fought in Bosnia but also came to Anatolia to fight against the forces of Mehmed Ali Pasha (Kavala). However, his troops had to return since a peace treaty was signed before his forces took part in the war. ${ }^{23}$

\footnotetext{
${ }^{13}$ Sel Turhan, ibid., p. 158-159.

${ }^{14}$ For his part in the war, see, Hamdi Kreşevlakovic, Çengiç Beyleri, Translated by İsmail Eren, Şehir Matbaası, İstanbul 1960, p. 56.

${ }^{15}$ Sel Turhan, ibid., p. 162-163; Griffe, ibid., p. 179.

${ }^{16}$ Governor of a Sanjak. See, Redhouse Yeni Türkçe-İngilizce Sözlük, Redhouse Yay., İstanbul 1979, p. 803.

${ }^{17}$ Mehmed Süreyya, Sicill-i Osmanî yahud Tezkere-i Meşâhir-i Osmaniyye, vol. III, Matbaa-i Amire, İstanbul 1311, p. 569; Griffe, ibid., p. 181.

${ }^{18}$ DAB., HAT., nr:421/21715, 19 Cemaziyelevvel 1248/24.10.1832 tarihli rapor.

${ }^{19}$ DAB., HAT., nr:439/22127, 21 Ramazan 1248/11.02.1833.

${ }^{20}$ DAB., HAT., nr:421/21718, 29 Zilhicce 1248/19.05.1833.

${ }^{21}$ DAB., HAT., nr:438/22114, 29 Zilhicce 1248/19.05.1833.

${ }^{22}$ DAB., HAT., nr:479/23430, 29 Zilhicce 1248/19.05.1833.

${ }^{23}$ DAB., HAT., nr:428/21871, 29 Zilhicce 1248/19.05.1833; HAT., nr:358/20031, 19 Receb 1248/12.121832.
} 


\section{Herzegovina Mutasarrifate}

\section{a. Management and Contention}

Ali Pasha has been a symbol of both integrity and state authority for Herzegovina until $1849 .{ }^{24}$ However, the people who were disturbed with this authority immediately took action and they accused Ali Pasha of oppressing and persecuting the population. ${ }^{25}$ In particular, Serbian Milos, who could not act freely due to the activities of Ali Pasha, did not ignore even the smallest event and complained to Istanbul on every opportunity, accusing Pasha of oppressing the public, in order to damage Ali Pasha's reputation in Istanbul. ${ }^{26}$ Because of this, Pasha was often exposed to Istanbul's warnings during his life as an administrator. ${ }^{27}$ Ali Pasha defended himself against these charges by saying that the allegations were unfounded and that he did not demand anything from the public except for the requirements of the legal authorities that the state assigned to him. Nevertheless, he declared the fact that he has taken the warnings from Istanbul into consideration and never disregarded the orders of the Sultan hitherto and that no such thing would ever happen. As far as he was concerned, he was working day and night for the welfare and happiness of the people, not for persecution and oppression. ${ }^{28}$ Ali Pasha, suffering from the allegations, wrote a letter and then sent to Istanbul: "Sir, I do not take even an $a k c e^{29}$ from the poor in our sanjak ${ }^{30}$ other than the installment of the property once every six months. It is alleged that we persecute and oppress the public. May Allah protect those who suffer from slander. Amen." ${ }^{31}$

Although Ali Pasha did not accept the accusations against him, his relations with the Bosnian governors ${ }^{32}$ and Istanbul have always been tense. As early as 1834, reports mentioning that Ali Pasha had not imposed the orders from the capital, ignored modernization and continued the old order in Herzegovina reached Istanbul. ${ }^{33}$ For example, the redif $f^{34}$ units which were supposed to be assembled from the region in 1836 could not have been rallied for a long time due to Ali Pasha's opposition. ${ }^{35}$ It was a particular issue of disturbance that after the captaincy was abolished, Ali Pasha confiscated the property of old captains and gave them to his sons to manage. The first troubles were with Hasan Beg Resulbegović and Smail Aga Čengić, who was both wise and mighty and supported him during the whole struggle. According to the people of Gacka, Smail Aga lost his life because of this competition. The rumors in the region indicated that Smail Aga was killed by Montenegrins in Mleticka on 23 September $1840^{36}$, as a result of an agreement between Ali Pasha and Montenegro Vladika Petar Njegos. ${ }^{37}$ Djilas, who is an expert on Montenegrin history, also supports these claims. He tells that Ali Pasha was free from a real enemy when Smail Aga died. According to him, this was

\footnotetext{
${ }^{24}$ Zafer Gölen, Tanzimat Dönemi Bosna İsyanları (1839-1878), Alter, Ankara 2009, p. 25.

${ }^{25}$ DAB., HAT., nr:634/31306, 29 Zilhicce 1251/16.04.1836.

${ }^{26}$ DAB., HAT., nr: 688/33367, 3 Cemaziyelevvel 1250/07.09.1834.

${ }^{27}$ DAB., HAT., nr: 644/31546, 19 Zilhicce 1254/15.03.1839.

${ }^{28}$ DAB., HAT., nr:688/33367-A, 29 Zilhicce 1250/28.04.1835.

${ }^{29}$ Small silver coin, asper (the basic unit Ottoman Money system, one third of a para). See, Redhouse Yeni TürkçeIngilizce Sözlük, Redhouse Yay., İstanbul 1979, p. 33.

${ }^{30}$ Subdivision of a province (vilayet). See, Redhouse Yeni Türkçe-İngilizce Sözlük, Redhouse Yay., İstanbul 1979, p. 983; Pars Tuğlacı, Okyanus Ansiklopedik Sözlük, vol. VIII, Cem Yay., İstanbul 1980, p. 2486.

${ }^{31}$ DAB., HAT., nr:688/33367, 3 Cemaziyevvel 1250/07.09.1834.

32 For the causes of Bonian Governor Vecihi Paşa's inconvenience see, DAB., HAT., nr: 644/31546, 25 Receb 1854/14.10.1838; HAT., nr: 637/31402, 10 Şaban 1854/29.10.1838.

${ }^{33}$ Sel Turhan, ibid., p. 176-177, 264.

${ }^{34}$ Troops of the militia. See, Redhouse Yeni Türkçe-İngilizce Sözlük, Redhouse Yay., İstanbul 1979, p. 951.

${ }^{35}$ DAB., HAT., nr: 327/19004.

${ }^{36}$ Kreșevlakovic indicates the date of death as 6 October 1840. See, Kreșevlakovic, ibid., p. 57.

${ }^{37}$ Başagiç, ibid., p. 239-241; Kreşevlakovic does not mention such a conspiracy in his book about the Çengiç family history. Since he does not mention such rumors even though he refers to Başagiç, it means that he does not find the allegations convincing. See, Kreşevlakovic, ibid., p. 57.
} 
how the Montenegrin Vladika took his revenge on Smail Aga, who caused the death of his relatives in the Battle of Grahova. ${ }^{38}$

With the initial implementation of the Tanzimat in Bosnia in 1840, a new matter of discontent occurred in the region. Although Ali Pasha was in fact against the Tanzimat, he seemed to support the state. Ali Pasha silently opposed the edict because he knew that if the Tanzimat were applied, he would lose all of his authority. However, he really did not have to do much, since not only him but also all the Bosnians were against the implementation of the Tanzimat. Refraining from the possibility of a new turmoil, the government had postponed the implementation of the Tanzimat in Bosnia for an indefinite period. ${ }^{39}$

As Ali Pasha strengthened his power, he began to put more and more pressure on the public, both for public works and personal ambitions, which led to complaints. At these times, many petitions regarding "persecution and oppression" caused by Ali Pasha's acts were frequently sent to Istanbul. According to some authors such as Ivo Andric, Ali Pasha was taxing even the unborn children and the families of the dead. He and some others claim that the phrase "stout as if imposed taxes on Bosnia" originated from the tax that Ali Pasha put on the public. ${ }^{40}$ However, Istanbul believed that the situation was not as bad as it was claimed. According to the capital, the main reason for the complaints was that the reaya ${ }^{41}$ shifting the border of Austria was getting insolent. The main cause of stress for Istanbul was that even the smallest event made it to European newspapers, tarnishing the image of the Ottoman Empire in Europe. That is why Istanbul called not only Ali Pasha but also all the administrators in the region to be careful. ${ }^{42}$ Istanbul, no longer able to neglect the increasing complaints, called Ali Pasha to the capital in 1841. Pasha did not obey this request saying that "Istanbul can see my head but it will never be with my body." 43 Later, it is seen that Ali Pasha, who became drunk with the absolute power he obtained, had gone so far as to say that "There is a sultan in Istanbul but I am the sultan in Mostar." 44

By the 1850s, Istanbul finally decided to implement the Tanzimat in Bosnia. Ali Pasha, who always acted with caution when it came to the matter of Tanzimat, made a big mistake and started to directly oppose the Tanzimat. The discontent of him and the other opponents drove Bosnia into a great chaos. However, Istanbul, regardless of considering the real culprits in the rebellion, decided to solve the problems in Bosnia fundamentally, and sent the most brutal general, Omer Lutfi Pasha to Bosnia. Basagić claims that Omer Pasha, the "sworn enemy of the Bosnians", was sent "by others with the intention to destroy Bosnia". However, Basagić is silent about who these others were. ${ }^{45}$ Upon his arrival, Ali Pasha said at a gathering in Mostar, "If we do not stop Omer Pasha now, Bosnia will not belong to Bosnians in 30 years. "46 Basagić tells another version of this statement. According to him, when Hayreddin Pasha, the newly appointed governor of Bosnia, visited Ali Pasha in his farm in Buna, Ali Pasha told the

\footnotetext{
${ }^{38}$ Adil Zülfikarpasic, The Bosniak, Hurst \& Company, London 1998, p. 7.

${ }^{39}$ Başagiç, ibid., p. 249; Zafer Gölen, Tanzîmât Döneminde Bosna Hersek, TTK, Ankara 2010, p. 77.

${ }^{40}$ Ivo Andric, The Development of Spiritual Life in Bosnia under the Influence of Turkish Rule, Duke University Press, Durham and London 1990, p.26, 80; Andrew G. Bostom, "Jihad Conquests and the Imposition of Dhimmitude-A Survey”, The Legacy of Jihad Islamic Holy War and the Fate of Non-Muslims, Edited by Andrew G. Bostom, Prometheus Books, New York 2005, p. 67.

${ }^{41}$ The tax paying subjects of the Ottoman Empire; non Muslim subjects of the Ottoman Empire; the Christian subject. See, Redhouse Yeni Türkçe-İngilizce Sözlük, Redhouse Yay., İstanbul 1979, p. 951.

${ }^{42}$ DAB., I.HR., nr: 14/686, 27 Ramazan 1257/12 Kasim 1841.

${ }^{43}$ Sel Turhan, ibid., p. 265.

${ }^{44}$ A. Popovic, "Ridwan Begović Ali Pasha", The Encyclopaedia of Islam-New Edition, vol.VIII, E. J. Brill, Leiden 1995, p. 520; Griffe, ibid., p. 186.

${ }^{45}$ Başagiç, ibid., p. 254-255; Griffe, ibid., p. 116-117.

${ }^{46}$ Misha Glenny, Balkanlar 1804-1999. Milliyetçilik, Savaş ve Büyük Güçler, Translated by Mehmet Harmanc1, İstanbul 2001, p. 84.
} 
governor that "If you apply Tanzimat in Bosnia Herzegovina, you will not be able to sustain them for even thirty years.". ${ }^{47}$

Ali Pasha sent a letter to Istanbul on January 30, 1851, as a final move after the loss of the Mostar War on February 10, 1851, on how loyal he was to the state. He wrote that the rebellion was caused by a group of impertinent mob, and that despite his advice and warnings the rebels did not listen to him. Pasha has given himself away with these words. Because everybody knew that there was no one in Herzegovina who would not listen to his word at that time. Istanbul, on the other hand, did not utter a single word about the way the rebellion emerged up until that date, and did not even bother to respond Ali Pasha. ${ }^{48}$ Thereupon, he and his son Ridvan Pasha surrendered to Skender Pasha in Mostar and his eldest son Rustem Pasha surrendered to Omer Pasha in Sarajevo, in the hopes of saving their lives. The three were arrested on February 17, 1851, to be sent to Istanbul on charges of "opposing the state's policies and encouraging the people to revolt." In order to show the power of the Ottoman army to the public, Skender Pasha made Ali Pasha trot around the city in only his underpants on a scabby donkey, while his son Hafiz Pasha was made to hold the reins. ${ }^{49}$

\section{b. Other Activities}

It is observed that in his time, serious public works were being done in Herzegovina. Roads, bridges and fortresses were built all over Herzegovina. The infertile land of Herzegovina has been rehabilitated and many agricultural products such as corn, rice, potato and tobacco, as well as viniculture, have started to be produced in Herzegovina. He imported figs, pomegranates and peach seedlings on his account and paved the way for their cultivation. ${ }^{50}$

Besides increasing agricultural production, he has built a large complex including many buildings along Bregava River. His activities have caused many complaints. It is understood that especially the Christians living in Herzegovina were very comfortable with the situation. ${ }^{51}$ The buildings were expropriated by the state when Cevdet Pasha was the Bosnian Inspector and were transformed into barracks. ${ }^{52}$ Some of those buildings destroyed during the 1993-95 war were later repaired in 2007. ${ }^{53}$

Ali Pasha has also dealt with tax collection. For example, he was one of the bidders for the contract of customs duties of the Dubrovnik pier in 1839 but has not won the auction, even though he has given 15,000 cents more. But even in this case, the state has been careful not to hurt Ali Pasha, and informed him that he has not been granted the contract since it was given to the previous owner as ccakllk $^{54}$; that is, it was a life-time tenancy. ${ }^{55}$

After Ali Pasha died, the thing that bothered the state most about him was about the privileges he granted to some Austrian merchants without consulting the capital. These traders opened factories especially in Herzegovina and made timber production. However, when Omer Pasha Latas abolished these privileges after Ali Pasha died, they demanded these privileges to be continued by showing the contracts they had signed with Ali Pasha. However, when Istanbul

\footnotetext{
${ }^{47}$ Başagiç, ibid, p. 258.

${ }^{48}$ DAB., I.DH., nr: 229/13736, appendix: 4, 27 Rebiülevvel 1267/30 Ocak 1851; nr:229/13736, 27 Rebiülahir 1267/01.03.1851.

${ }^{49}$ Başagiç, ibid., p. 259, 261; Griffe, ibid., p. 10; Gölen, Tanzimat Dönemi Bosna İsyanları, p. 97-98; Bilge, ibid., p. 51.

${ }^{50}$ Başagiç, ibid., p. 251-252; Popovic, ibid., p. 520; Griffe, ibid., p. 182-185

${ }^{51}$ DAB., I.HR., nr: 14/686, appendix: 1.

52 DAB., A.MKT.MHM., nr: 289/43, 25 Receb 1280/05.01.1864; A.MKT.MHM., nr: 203/17, 8 Muharrem 1281/13.06.1864.

${ }^{53}$ Bilge, ibid., p. 51.

${ }^{54}$ Family estate given by the Sultan. See, Redhouse Yeni Türkçe-İngilizce Sözlük, Redhouse Yay., İstanbul 1979, p. 897.

${ }^{55}$ DAB., HAT., nr: 530/26135, 17 Muharrem 1255/02.04.1839.
} 
did not acknowledge these contracts since they were not signed with the state, this matter soon became an international problem between Austria and the Ottoman state. The Austrian government wanted compensation for the merchants' losses, while Istanbul initially rejected Austria's claims. When the Ottoman Empire had to stop the military operation due to Austria's firm intervention after the 1852/53 Montenegro expedition, the Count of Leningen was sent to Istanbul in order to settle the affairs between the two countries. One of the issues to be settled was related to Austrian merchants who were allowed by Ali Pasha to chop trees and made due investments in Herzegovina. Istanbul agreed to pay compensations at the end of negotiations. ${ }^{56}$ Especially Ernest Sönefeld, Löven Kloki and Tuan Kuvic, who claimed to be victims, did not let the matter rest. The problems arising from the privileges given by Ali Pasha continued to engage the state even for many years. ${ }^{57}$

\section{c. Struggle with Montenegro}

Ali Pasha was very sensitive about the protection of the districts where he commanded. ${ }^{58}$ He was especially attentive about the events taking place on the Montenegrin. He reported even the slightest violation and inconvenience on the border to the capital and often asked for permission for intervention. ${ }^{59}$ Even when his intervention requests were denied, Pasha responded most of the attacks. However, the main conflict was caused by Grahova. The Ottomans regarded Grahova as a part of Herzegovina and the Montenegrins as their own ancient land. Neither side could gain superiority in the battle of 1836. Both sides, however, claimed that they were the victors. According to Basagić, Ali Pasha, who became tired of the Montenegrins' intervention in Grahova, called all the Hersekites under arms. In particular, with the appropriate measures taken by Ali Pasha's comrade in arms Smail Aga Čengić, the Montenegrin army was forced to leave the battlefield, leaving many dead. ${ }^{60}$ The struggle resulted with an act on the status of Grahova on October 20,1838. According to the agreement signed between Bosnian Governor Mehmed Vecihi Pasha, Mutasarıf of Herzegovina Ali Pasha and Montenegro Vladika's Petar, Grahova was accepted as a neutral territory. ${ }^{61}$

Two further agreements were made between Ali Pasha and Petar on 24 September 1842 and 9 November 1843 on the status of Grahova. Both agreements concerned the settlement of borders and the prevention of attacks. Istanbul, naturally, never recognized these agreements. ${ }^{62}$

\section{His Death}

During the military operation he had organized in the Pusovina region, Omer Lutfi Pasha also took Ali Pasha and his son Hafiz Pasha with him, who were in detention. On March 20, 1851, Ali Pasha died under suspicious circumstances in a place called Ivanska in the Dobrina Plain, four hours away from Banja Luka. He was buried in a small tomb in the courtyard of Ferhat Pasha Mosque in Banja Luka. Two separate claims about his death have been put forward. According to the first one, Ali Pasha somehow managed to take the weapon of one of the guards and committed suicide. According to the second one, one of the guards fell down due to exhaustion, and at that time the rifle in his possession was discharged when it fell on the

\footnotetext{
${ }^{56}$ Zafer Gölen, “1852-53 Karadağ Askerî Harekâtı ve Sonuçları”, History Studies, Issue.1, Samsun 2009, p. 255.

${ }^{57}$ For details see, DAB., A.MKT.UM., nr: 151/45, 1 Cemaziyelevvel 1270/30.01.1854; A.MKT.MVL., nr: 96/44, 24 Recep 1274/10.03.1858; Zafer Gölen, "Tanzimat Döneminde Osmanlı Devleti’nin Bosna Hersek Ormanlarını Korumaya Yönelik Çabaları”, Belleten, vol. LXXX, Issue. 288, Ankara 2016, p. 548-556.

${ }^{58}$ He was uncomprimising not only against Montenegrins, but against anyone who trespassed Herzegovina territory. On one occasion, in 1845, he executed three Austrians who entered his territory without pernission. Austrian emissary in Istanbul issued a protest about this incident and Ali Pasha was warned to act more carefully in the future. See, DAB., A.MKT.MHM., nr: 753/5, 13 Rebiülevvel 1261/21.03.1845.

${ }^{59}$ DAB., HAT., nr: 434/22001, 29 Zilhicce 1249/19.03.1833.

${ }^{60}$ Başagiç, ibid., p. 232-233; Kreşevlakovic, ibid., p. 57.

${ }^{61}$ Zafer Gölen, “Karadağ Devleti'nin Doğuşu: Osmanlı-Karadağ Sınır Tespit Çalışmaları (1858-60)”, Belleten, vol. LXXVIII, Issue 282, Ankara 2014, p. 670.

${ }^{62}$ Gölen, Karadağ Devleti'nin Doğuşu, p. 670; Popovic, ibid., p. 520.
} 
ground, and the bullet hit Ali Pasha under the chin through his head, causing him to lose his life. The matter was so important that it was immediately reported to Istanbul. ${ }^{63}$ Istanbul received both claims skeptically and immediately initiated an investigation about the death of Ali Pasha. ${ }^{64}$ However, it was consistently stated in the reports from Bosnia and in the discussions that Ali Pasha died by accident. Thereupon, Captain Halil Bekir Aga, Sergeant Yunus and the alleged perpetrator, who was the guard on duty, soldier Yakup, who were the witnesses of the incident that night, were brought to Istanbul and they were interrogated separately and repeatedly in the Dâr-ı Şûrâ-yi Askerî. There was also no result from these inquiries. Despite all the efforts of Istanbul, the mystery regarding Ali Pasha's death had not been able to be solved. Istanbul pursued the inquiries for a long time, but had not received any results. In the end, Istanbul, being unable to resolve the issue, was forced to drop the case, and it was announced that Ali Pasha accidentally lost his life. ${ }^{65}$ Ridvan Pasha and Rustem Beg, the sons of Pasha who were in exile in Bursa, were informed of this declaration via provincial government in Bursa on February 19, 1852. ${ }^{6}$

Although the public seemed to believe the Istanbul's verdict that Ali Pasha was killed by accident, neither the public nor the researchers paid much attention to the official explanation of the cause of his death. Krsmarik expresses that Omer Lutfi Pasha got rid of Ali Pasha. ${ }^{67}$ Basagić and Griffe also define the incident as an assassination. According to them, Ali Pasha was killed because Omer Lutfi Pasha was afraid that Ali Pasha would tell the sultan the truth about himself. Evans describes the incident as follows:

\begin{abstract}
"Ali Pasha was sore vexed at his abasement, and straightway began to rail at Omer Pasha, and amongst other things he said: 'Why dost thou torment me thus? Thou art a Vlach and the son of a Vlach! From whom hast thou authority to drag me thus? Aye, and had I taken arms against the Sultan himself, it is not to thee belongs the right to treat me as one taken in battle, wert thou three times Seraskier. Therefore, O unclean Vlach! Send me rather to my Padishah, that he may judge me, and vex me not in my old age'. But whwn Omer Pasha heard this, he feared lest peradventure he himself should suffer damage at Stamboul; for Ali Pasha had many friends there amongst those in high places, to whom he was wont to send much money from Herzegovina. So Omer Pasha, turning these things over in his mind, in the end perceived that it were better if Ali Pasha were no longer of this World. And lo! At night, at two of the clock, was heard the sound as of a shot, and there came tidings to Omer Pasha that it had so chanced a gun had gone off, and behold the ball had passed through Ali Pasha's head. Thus died Ali Pasha, Rizvanbegović on twentieth day of March, 1851."68
\end{abstract}

Many researchers share this opinion. ${ }^{69}$ For example, Arbuthnot writes, "Old Ali Pasha was made a prisoner and sent in chains to Sarajevo. That place he never reached, for he was shot, accidentally it is alleged, by a Turkish soldier while on his way thither. The circumstances of his death will hardly bear an enquiry, and do not reflect much credit on the successful Omer, to whom the blame, as well as the glory he acquired in all else, must attach.”. But he thinks that Ali Pasha deserves this treatment and characterizes him as tyrant. ${ }^{70}$ Zülfikarpasić also writes that Pasha "was killed in a cruel and humiliating manner by Omer Pasha despite the fact that he

${ }^{63}$ DAB., A.MKT.NZD., nr: 34/19, 12 Receb 1267/13.05.1851.

${ }^{64}$ DAB., A.MKT.MHM., nr: 37/51, 16 Zilhicce 1267/12.10.1851.

65 Gölen, Tanzimat Dönemi Bosna İsyanlart, p. 99-100; Bilge, ibid., p. 51; Nicolae Jorga, Osmanlı Imparatorluğu Tarihi, vol. V, Translated by Nilüfer Epçeli, Yeditepe Yay., İstanbul 2005, p. 349. Mehmed Sureyya also supports the claims of the state. He writes that Ali Pasha died in an accident. See, Mehmed Süreyya, ibid., p. 569.

66 DAB., A.MKT.MVL., nr: 49/95, 17 Rebiülahir 1268/09.02.1852; A.MKT.MVL., nr: 50/21, 19 Rebiülahir 1268/11.02.1852.

${ }^{67}$ J. Krscmarik, “Bosna Hersek-Tarih”, İslâm Ansiklopedisi, MEB, İstanbul 1979, p. 732.

${ }^{68}$ Arthur John Evans, Through Bosnia and the Herzegovina on Foot during the Insurrection August and September 1875, Longmans, Green, and Co., London 1876, p. 349-350.

${ }^{69}$ Griffe, ibid., p. 11-12, 120; Başagiç, ibid., p. 261-263; Sel Turhan, ibid., p. 265.

${ }^{70}$ George Arbuthnot, Herzegovina; or Omer Pacha and the Christian Rebels, Longman, Green, Longman, Roberts, \& Green, London 1862, p. 124. 
was on Istanbul's side during the Gradascevic movement."71 İmamović also thinks the same thing with Zülfikarpasić and says, "Rizvanbegović's betrayal of his fellows from the same social class, Hüssein Captain and other Bosnian notables, indicates that he completely misevaluated the political conditions and tendencies within the empire. At a time when the institution of landed aristocracy was entirely abolished in the empire, it is quite unusual that he, as an experienced person and a leader of the people, could maintain his position in Herzegovina just owing to the fact that he just made a perfidious as well unsavoury job at a critical time."72

After Ali Pasha's death, all of his children and their families were sent to Istanbul. The family was forced to reside in Bursa for a while. ${ }^{73}$ During this compulsory residence, the state took necessary cautions for the family not to be in despair. For this purpose, a salary of 7,500 piaster was granted to the family. Of this total, 1,250 piaster was allocated to Ridvan Pasha, 1,250 piaster was allocated to Rustem Beg, and the remaining 5,000 piaster was shared among the rest of the family. ${ }^{74}$ However, it is understood that some members of the family were uncomfortable with this division of property in the following years. Pasha's wife Hadji Nuriye Hanim and the two of his daughters have asked for help from the government, claiming that Ridvan Pasha seized the majority of the property and they were left with an insignificant portion. Thereupon, the government intervened in order to ensure an equal sharing of the property. ${ }^{75}$ The properties owned by the family in Herzegovina were administered by the state until they were returned to the family, and a part of the obtained income was also given to the family. ${ }^{76}$ Another issue was the claims of the people who argued that they were not paid for their services or the properties they had paid for have not been transferred to them, after the Pasha's death. ${ }^{77}$ In fact, Istanbul had to set up a commission in Istanbul to investigate these claims. $^{78}$

When, after five years, Ali Pasha's reputation was rehabilitated the restrictions on the family have been removed. ${ }^{79}$ In 1856, the heirs asked that they should be paid the accumulated rent of the mansion and other buildings in Mostar by the treasury. The request was accepted by the government and orders were issued to the Ministry of Finance for payment. ${ }^{80}$ His mansion in Stolac, which was still under construction during the inspectorship of Cevdet Pasha in Bosnia, was bought by the state. Pasha's son, District Governor in Teke Ridvan Pasha, appointed Joyozade Omer Aga due to the kinship with Ali Pasha for courtesy of the sale. ${ }^{81}$ The mansion was purchased with a price of 50.000 piaster to be used as barracks in exchange for Ali Pasha's debts to the state. ${ }^{82}$

\section{His Foundations (Waqfs)}

As it is known, when the notables in Islamic countries offer all or some of their assets to the public interest, this is called waqf (foundation). Thus, the individuals transfer their revenues for an unlimited period of time to the foundations, which they have founded or previously existing ones, in order to support them and help the needy. Ali Pasha also devoted part of his properties in conformity with this tradition.

\footnotetext{
${ }^{71}$ Zülfikarpasic, ibid., p. 17.

72 Mustafa İmamović, Boşnakların Tarihi, Translated by Hüseyin Gül and Cenita Özgüner, Tarih Vakfi Yurt Yay., İstanbul 2018, p. 424.

${ }^{73}$ DAB., A.MKT.MVL., nr: 49/95; A.MKT.MVL., nr: 50/21.

${ }^{74}$ DAB., A.MKT.NZD., nr: 68/49 26 Safer 1269/09.12.1852.

${ }^{75}$ DAB., A.DVN., nr: 103/64; A.MKT.DV., nr: 79/99, 10 Şaban 1271/28.04.1855.

${ }^{76}$ DAB., A.MKT.NZD., nr: 168/33, 12 Safer 1272/24.10.1855.

77 DAB., I.MVL., nr: 242/8770, 2 Zilkade 1268/18.08.1852; DAB., A.MKT.MHM., nr: 276/331, 26 Rebiülevvel 1280/10.09.1863.

${ }^{78}$ DAB., HR.MKT., nr: 73/25.

${ }^{79}$ Griffe, ibid., p. 92.

${ }^{80}$ DAB., A.MKT.NZD., nr: 189/86, 5 Zilhicce 1272/07.08.1856.

${ }^{81}$ DAB., A.MKT.MHM., nr: 335/93, 30 Muharrem 1282/25.06.1865.

${ }^{82}$ DAB., A.MKT.MHM., nr: 332/64, 24 Zilhicce 1281/20.05.1865; A.MKT.MHM., nr: 303/17.
} 
Ali Pasha donated the coffeehouses and shops in Stolac Grand Bazaar, the shops and cellars under the mosque in the Hisaralt1 Quarter, the shops opposite the mosque, fifty percent share of the bakery, the mills, all of his vineyards in various part of the town and 3,000 piaster cash money. ${ }^{83}$

Out of the income of this foundation, 500 piaster of income was to be given as salary to the imam of Hisaralti Mosque. In return, Pasha demands from the imam a Yasin-i Sharif every day and a hatim ${ }^{84}$ during the month of Ramadan for himself and his descendants. A portion of the income would be spent on repair and illumination expenses of the mosque. During Ramadan, food would be cooked and distributed to the poor. The foundation trustees would be their own sons, and after all these things are done, the remaining money would be divided among the brothers. ${ }^{85}$

Ali Pasha has four foundation registries in Mostar. Firstly, he devoted all the olive trees, mulberry groves, and mills with all the equipment in Buna, with the exception of the house and vegetable gardens, for the repair and maintenance expenses of the New Mosque he has built in Buna. According to the foundation, the imam of the New Mosque, whoever he was, was to be paid five piaster for each prayer every day and the muezzin was to be paid 40 paras. ${ }^{86}$ In return, Pasha demanded that prayers would pray for his and his descendants' souls. Imams were obliged to read Yasin-i Sharif every day for his soul. The trustees of this foundation are his sons. They would be able to share and spend the remaining foundation revenues after all expenses were made. ${ }^{87}$

The second foundation in Mostar is a shop and three houses with their outbuildings in Mostar Keyvan Beg Quarter, the Upper Market Caravanserai and adjacent shops, a vineyard in Karsiyaka, a vineyard under the church, a mansion and the gardens on the Palace road. He devoted all of these properties to the tekke ${ }^{88}$ he had built. With the revenues of the foundation, before all else the needs of the sheikh and his disciples would be provided for and the remaining revenues would be distributed equally between his wives Nuriye and Mislicihan Hanim. ${ }^{89}$ When the family was sent in exile to Bursa after Ali Pasha's death, Hadji Nuriye and Mislicihan Hatun were not sent any due incomes by the foundation. Upon this, the two wives appealed to the state with a joint petition for the payment of their income between 1267 (1850) -1276 (1859). ${ }^{90}$

In the third foundation in Mostar, Pasha's 33 houses in various neighborhoods of Mostar, his mill in the Bestice neighborhood and vineyards in the vicinity of Lower Mahala Hadjilar Sofa were entrusted to the wages and expenses of the sheikh and dervishes of the tekke, which he built near Hadjilar Sofa. In return, Pasha again required Yasin-i Sharif to be read for himself and his family. The trustees of this foundation were his sons, and if the incomes of the foundation were higher than the expenses, the children would share the money among themselves. ${ }^{91}$

The last foundation of Pasha in Mostar is related to the caravanserai, grocery store, bakery, coffee house and 50 acres of land near the bridge on the bank of the river of Buna village. All the income has been devoted to the maintenance, repair and other expenses of the

83 Bosna Hersek Vakfiyeleri, vol. IV, Vakıflar Genel Müdürlüğ̈̈ Yay., Ankara 2016, p. 1508-1509; DAB., A.MKT.MHM., nr: 332/64, 24 Zilhicce 1281/20.05.1864.

${ }^{84}$ Recitation of the Quran from begining to end. See, Pars Tuğlacı, Okyanus Ansiklopedik Sözlük, vol. III, Cem Yay., İstanbul 1980, p. 1016.

${ }^{85}$ Bosna Hersek Vakfiyeleri, p. 1509-1510.

${ }^{86}$ One fortieth of a kurush (piastre). See, Redhouse Yeni Türkçe-Ingilizce Sözlük, Redhouse Yay., İstanbul 1979, p. 917; Pars Tuğlacı, Okyanus Ansiklopedik Sözlük, vol. VII, Cem Yay., İstanbul 1980, p. 2274.

${ }^{87}$ Bosna Hersek Vakfiyeleri, vol. II, Vakıflar Genel Müdürlüğ̈̈ Yay., Ankara 2016, p. 624-625.

${ }^{88}$ Dervish lodge. See, Pars Tuğlacı, Okyanus Ansiklopedik Sözlük, vol. IX, Cem Yay., İstanbul 1980, p. 2807.

${ }^{89}$ Bosna Hersek Vakfiyeleri, vol. II, p. 626-627.

${ }^{90}$ DAB., A.MKT.UM., nr: 404/43.

${ }^{91}$ Bosna Hersek Vakfiyeleri, vol. II, p. 628-630. 
mosque he has built in Buna village. ${ }^{92}$ The common ground of these foundations is the fact that all of them are beneficial to the family and they guarantee their future.

After Ali Pasha died, the family could not benefit from the income of these foundations since they were exiled to Bursa. In 1858, Mehmed Kâmil and Mehmed Arif, the sons of Zulfikar Nafiz Pasha, demanded that their shares to be paid from relevant income. Upon this, Herzegovina mutasarif was given orders to investigate these allegations and act accordingly. ${ }^{93}$

\section{His Family}

Ali Pasha had five spouses. Fatma Hanim ${ }^{94}$ and Zulfikar Nafiz Pasha ${ }^{95}$ were his children from Ulah Mara; Mehmed Ridvan (Rizvan) Pasha ${ }^{96}$, Uma Hanim ${ }^{97}$ and Habîbe ${ }^{98}$ were his children from Refifa Hanim who was the daughter of Ali Pasha of Janina; Emine ${ }^{99}$ and Sakire Hanim ${ }^{100}$ were his daughters, Rustem Refet Beg ${ }^{101}$ was his son from Hadji Nuriye Hanim and Mehmed $\mathrm{Ali}^{102}$ was his son from Mislicihan Hatun. ${ }^{103}$

Ali Pasha not only provided for them by establishing foundations but also obtained rankings for their children from time to time using his position. For example, in 1848, his son Ridvan Beg was given the title of mîr-i mîran ${ }^{104}$, and Rustem Beg was awarded the rank of kapucibasi. ${ }^{105}$ Ali Pasha explicitly demanded these ranks ${ }^{106}$ and Istanbul, considering the critical state of Herzegovina, approved his demands. ${ }^{107}$

\footnotetext{
${ }^{92}$ Bosna Hersek Vakfiyeleri, vol. II, p. 631-632.

${ }^{93}$ DAB., A.MKT.DV., nr: 125/32.

${ }^{94}$ He died when his father was still alive. See, Griffe, ibid., p. 9.

${ }^{95}$ Zulfikar Beg is commander of the forces, and governor of Stolac , the stronghold of Herzegovina. See, Wilkinson, ibid., p. 71. He died when his father was still alive. Zulfikar Beg was appointed as the governor of Bosnia on 10 August 1850 but died on the road while accompanying Hayreddin Pasha. He fell ill in Imochka on 27 Safer 1267/01.01.1851 and died. Griffe claims that he was killed by the governor. See, Başagiç, ibid., p. 258; Griffe, ibid., p. 9, 12, 218. His father informed Istanbul of his death on 30 January 1851. DAB., I.DH., nr: 229/13736, Ek:4, 27 Rebiülevvel 1267/30.01.1851. Zulfikar Nafiz Bey's son is famous poet Arif Hikmet Bey. He is known as Herzegovinian Arif Hikmet. He was born in Mostar on 23 November 1839 and died in Istanbul on 10 May 1903. See, İbnü'l-Emin Mahmud Kemal İnal, Son Asır Türk Şairleri (Kemâlü'ş-Şuarâ), vol. II, Prepared by M. Kayahan Özgül, Atatürk Kültür Merkezi Başkanlığı Yay., Ankara 2000, p. 952-956; Popovic, ibid., p. 521. Herzegovinian Arif Hikmet fiercely opposed the Tanzimat which caused his grandfather's death and his family's demise. See, Metin Kayahan Özgül, Hersekli Arif Hikmet, Kültür ve Turizm Bakanlığı Yay., Ankara 1987, p. 28-33, 166-168.

${ }^{96}$ Griffe, ibid., p. 12, 219-220. Ridvan Beg could speak Arabic, with great facility. He had been to pilgrimage of Mecca, and had remained some time at Cairo, of which place he had acquired the idiom. See, Wilkinson, ibid., p. 73.

${ }^{97}$ Married to Mehmet Bey, son of Ibrahim Firdus, the Captain of Livanski. Died in Istanbul, in 1920. See, Griffe, ibid., p. 156, 219

${ }^{98}$ Ottoman poets. Was born in Herzegovina on h.1262/1845-46. Was died in Istanbul on March 1891. See, İbnü'lEmin Mahmud Kemal İnal, ibid., p. 715-716; Popovic, ibid., p. 521; Griffe, ibid., p. 169.

${ }^{99}$ Griffe, ibid., p. 221.

${ }^{100}$ DAB., A.DVN., nr: 103/64. Was died in İstanbul on h.1311/1913. Özgül, ibid., p. 5, 46; Griffe, ibid., p. 220-221.

${ }^{101}$ Mehmed Sureyya lists him among poets and writes that he died about 100 years after his father. See, Mehmed Süreyya, ibid., p. 569. Griffe notes that he was a poet who used Rifat as his pen name. Griffe, ibid., p. 169, 220. Rustem Bey died in 1861. See, DAB., A.MKT.NZD., nr: 415/36, 29 Rebiülahir 1278/03.11.1861. Rustem Bey held the rank of kapucubasi of Dergah-Ali. He used the name Refet instead of Rustem Refet. DAB., A.MKT.UM., nr: 206/32, 2 Zilhicce 1271/16.08.1855.

${ }^{102} \mathrm{He}$ was an Ottoman marshall (Müşir). He was born 1844 and died in Erzurum on h.1319/1901-1902. His son Hüsrev Gerede a close friend of Atatürk's and a commander in National Struggle.

See, Özgül, ibid., p. 46; Griffe, ibid., p. 3-4, 92-93, 151, 214-215.

103 Mehmed Süreyya, ibid., p. 569; Gölen, Tanzimat Dönemi Bosna İsyanları, p. 97, 99; Popovic, ibid., p. 521; Griffe, ibid., p. 214-215.

${ }^{104}$ Pasha who governs a province. See, Redhouse Yeni Türkçe-İngilizce Sözlük, Redhouse Yay., İstanbul 1979, p. 779.

${ }^{105}$ A high Officer.

${ }^{106}$ DAB., I.DH., nr: 169/8921, 5 Rebiülevvel 1264/10.02.1848.

${ }^{107}$ DAB., İ.DH., nr: 169/8921, 29 Rebiülahir 1264/04.04.1848.
} 


\section{Conclusion}

The Ottoman Empire, especially by the turn of $18^{\text {th }}$ century had to share its power with local Pashas in the distant provinces. These people were either former rebels or local notables. Mehmed Ali Pasha (Kavala), Ali Pasha (Janina) and Mustafa Pasha (Alemdâr) were the most well-known figures of this group. The notables were usually persons who helped the state during the periods of crisis. However, after a while, they also fell into disagreement with the state and almost all of them had a similar end as Ali Pasha has experienced. Ali Pasha was a disciplined soldier, a planning politician, a brave and hard-tempered man. ${ }^{108}$ He would do what he set his mind on and he would follow all the work until completion. He was never tired of working and he wanted his people to keep up with him. He was both daring and very cautious. Before he made his moves, he would give a thorough consideration and would act accordingly. However, as in the case of Osman Beg, he also knew to withdraw from the battlefield and wait. Ali Pasha actively took part in every development in Bosnia from 1813 to 1851, throughout the tumultuous period. The rise of Ali Pasha as a historical figure from the captaincy of a small place such as Stolac is a product of his own endeavor. In almost every incident until 1850, Ali Pasha succeeded to position himself in the right place. This successful strategy raised him from Stolac to the mutasarifate where he would be the absolute power in Herzegovina. The last senator of the Balkans would err once and pay for it with his life.

\section{Bibliography}

\section{A. Archive Sources}

DAB (Devlet Arşivleri Başkanlığı- The Head of the State Archives), A.MKT.DV., (SadaretMektubi, Deavi Kalemi Evrakı), nr: 79/99, 125/32.

DAB, A.MKT.MHM. (Sadaret-Mektubi, Mühimme Kalemi Evrakı), nr: 37/51, 276/331, 289/43, 303/17, 332/64, 335/93, 753/5.

DAB., A.MKT.MVL. (Sadaret-Mektûbi, Meclis-i Vâlâ Evrakı), nr: 49/95, 50/21, 96/44.

DAB., A.MKT.NZD. (Sadaret-Mektûbi, Nezaret ve Devair Kalemi Evrakı), nr: 34/19, 68/49, 168/33, 189/86, 415/36.

DAB., A.MKT.UM. (Sadaret-Mektûbi, Umum Vilayat) , nr: 151/45, 206/32, 404/43.

DAB., HAT. (Hatt-ı Hümayun), nr: 327/19004, 358/20031, 421/21715, 421/21718, 428/21871, 434/22001, 438/22114, 439/22127, 479/23430, 530/26135, 604/29542, 634/31306, 637/31402, 644/31546, 688/33367.

DAB., HR.MKT. (Hariciye Nezareti, Mektûbi Kalemi Evrakl), nr: 73/25.

DAB., I.DH. (Irade Dahiliye), nr: 169/8921, 229/13736.

DAB., I.HR. (Irade Hariciye), nr: 14/686.

DAB., İ.MVL. (İrade Meclis-i Vâlâ), nr: 242/8770.

\section{B. Other Sources}

Andric, Ivo, The Development of Spiritual Life in Bosnia under the Influence of Turkish Rule, Duke University Press, Durham and London 1990.

Arbuthnot, George, Herzegovina; or Omer Pacha and the Christian Rebels, Longman, Green, Longman, Roberts, \& Green, London 1862.

\footnotetext{
${ }^{108}$ DAB., HAT., nr: 327/19004, 29 Zilhicce 1251/16.04.1836.
} 
Başagiç (Recepaşiç), Safvet Beg, Bosna Hersek Tarihi (1463-1850), Translated by Saffet Atalay, Kastaş Yayınevi, İstanbul 2015.

Bilge, Mustafa L., "Ridvanbegoviç, Ali Pasha”, Türkiye Diyânet Vakfi İslâm Ansiklopedisi, vol. XXXV, Türkiye Diyânet Vakfi Yay., İstanbul 2008, pp. 50-51.

Bostom, Andrew G., "Jihad Conquests and the Imposition of Dhimmitude-A Survey", The Legacy of Jihad Islamic Holy War and the Fate of Non-Muslims, Edited by Andrew G. Bostom, Prometheus Books, New York 2005, pp. 24-124.

Evans, Arthur John, Through Bosnia and the Herzegovina on Foot during the Insurrection August and September 1875, Longmans, Green, and Co., London 1876.

Glenny, Misha, Balkanlar 1804-1999. Milliyetçilik, Savaş ve Büyük Güçler, Translated by Mehmet Harmanc1, İstanbul 2001.

Gölen, Zafer, “1852-53 Karadağ Askerî Harekâtı ve Sonuçları”, History Studies, Issue.1, Samsun 2009, pp. 212-296.

Gölen, Zafer, “Karadağ Devleti’nin Doğuşu: Osmanlı-Karadağ Sınır Tespit Çalışmaları (185860)", Belleten, vol. LXXVIII, Issue.282, Ankara 2014, pp. 659-698.

Gölen, Zafer, “Tanzimat Döneminde Osmanlı Devleti’nin Bosna Hersek Ormanlarını Korumaya Yönelik Çabaları”, Belleten, vol. LXXX, Issue.288, Ankara 2016, pp. 548-556.

Gölen, Zafer, Tanzimat Dönemi Bosna İsyanları (1839-1878), Alter, Ankara 2009.

Gölen, Zafer, Tanzîmât Döneminde Bosna Hersek, TTK, Ankara 2010.

Griffe, H. Mirgül Eren, Osmanlının Hizmetkarı Galip Ali Pasha Rızvanbegovic-Stocevic, Babil Yayın Dağıtım, Ankara 2005.

İbnü'l-Emin Mahmud Kemal İnal, Son Asır Türk Şairleri (Kemâlü'ş-Şuarâ), vol. II, Prepared by M. Kayahan Özgül, Atatürk Kültür Merkezi Başkanlığı Yay., Ankara 2000.

İmamović, Mustafa, Boşnakların Tarihi, Translated by Hüseyin Gül and Cenita Özgüner, Tarih Vakfi Yurt Yay., İstanbul 2018.

Jorga, Nicolae, Osmanlı Imparatorluğu Tarihi, vol. V, Translated by Nilüfer Epçeli, Yeditepe Yayınevi, İstanbul 2005.

Kreşevlakovic, Hamdi, Çengiç Beyleri, Translated by İsmail Eren, Şehir Matbaası, İstanbul 1960.

Krscmarik, J., “Bosna Hersek-Tarih”, İslâm Ansiklopedisi, MEB, İstanbul 1979, p.729-732.

Mehmed Süreyya, Sicill-i Osmanî yahud Tezkere-i Meşâhir-i Osmaniyye, vol. III, Matbaa-i Amire, İstanbul 1311.

Özgül, Metin Kayahan, Hersekli Arif Hikmet, Kültür ve Turizm Bakanlığ̣ Yay., Ankara 1987.

Popovic, A., "Ridwan Begović Ali Pasha", The Encyclopaedia of Islam-New Edition, vol. VIII, E. J. Brill, Leiden 1995, pp. 519-521.

Redhouse Yeni Türkçe-İngilizce Sözlük, Redhouse Yayınevi, İstanbul 1979.

Sel Turhan, Fatma, Eski Düzen Adına. Osmanl Bosna'sında İsyan (1826-1836), Küre Yay., İstanbul 2013.

Tuğlacı, Pars, Okyanus Ansiklopedik Sözlük, vol. III, VI-IX, Cem Yayınevi, İstanbul 1980.

Wilkinson, John Gardner, Dalmatia and Montenegro, vol. II, John Murray, London 1848.

Zülfikarpasic, Adil, The Bosniak, Hurst \& Company, London 1998. 